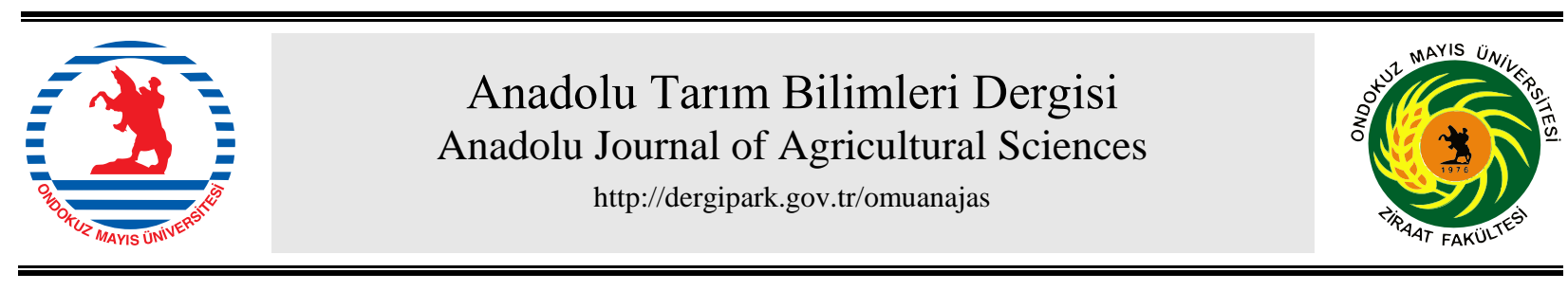

Araştırma/Research

Anadolu Tarım Bilim. Derg./Anadolu J Agr Sci, 32 (2017)

ISSN: 1308-8750 (Print) 1308-8769 (Online)

doi: 10.7161/omuanajas.287002

\title{
Erzurum İli meralarında doğal olarak yetişen farklı baklagil yem bitkilerinin nispi yem değerlerinin belirlenmesi
}

\author{
Esra Gürsoy $^{\mathrm{a}^{*}}$, Muhlis Macit ${ }^{\mathrm{b}}$ \\ ${ }^{a} \dot{I l}$ Gıda, Tarım ve Hayvancllık Müdürlüğü, Erzincan \\ ${ }^{b}$ Atatürk Üniversitesi, Ziraat Fakültesi, Zootekni Bölümü, Erzurum \\ * Sorumlu yazar/corresponding author: esra_gursoykaya@ @otmail.com \\ Geliş/Received 23/01/2017～Kabul/Accepted 15/05/2017
}

\begin{abstract}
ÖZET
Erzurum ili meralarında doğal olarak yetişen bazı baklagil yem bitkilerinin kimyasal kompozisyonu, Anahtar Sözcükler: kuru madde tüketimi (KMT), kuru madde sindirilebilirliği (KMS), ve nispi yem değerlerinin (NYD) Baklagil yem bitkisi belirlenmesi amaciyla yürütülen çalışmada, materyal olarak yonca (Medicago sativa), dă̆ İspanyol Kimyasal kompozisyon korungası (Hedysarum elegans), melez yonca (Medicago varia), kuş fiği (Vicia cracca), dağ fiği (Vicia Nispi yem değeri alpestris), tüylü fiğ (Vicia villosa), dağ üçülü (Trifolium montanum), üç başlı üçgül (Trifolium trichocephalum), kafkas üçgülü (Trifolium ambiguum), doğu taç otu (Coronilla orientatis), alaca taç otu (Coronilla varia L.) ve sarı çiçekli gazal boynuzu (Lotus corniculatus) kullanılmıştır.

İncelenen yem bitkileri arasında kuru madde (KM), ham kül (HK), ham yağ (HY), ham protein (HP), organik madde $(\mathrm{OM})$, asit çözücüde çözünmeyen yapısal karbonhidratlar (ADF), nötral çözücüde çözünmeyen karbonhidratlar (NDF), asit çözücüde çözünmeyen lignin (ADL) ve nispi yem değerleri (NYD) bakımından önemli farklılıklar gözlenmiştir $(\mathrm{P}<0.01)$. Baklagil yem bitkilerinin ortalama KMS, KMT ve NYD değerleri sırasılla \% 60.92-73.26, \% 2.46-3.90 ve 116.69-221.18 arasında değişmiştir.

Sonuç olarak, HY, HP ve HK bakımından zengin NDF, ADF ve ADL bakımından fakir olan yem bitkilerinin KMT, KMS ve NYD özellikleri bakımından tatminkâr sonuçlar verdiği kanaatine varılmıştır.
\end{abstract}

Determination of relative feed values of different legume forages grown as naturally in pastures of Erzurum Province

\section{ABSTRACT}

This study was carried out to determine the chemical composition, dry matter consumption (DMC), dry matter digestibilities (DMD) and relative feed values (RFV) of some legume forages grown naturally in the pastures of Erzurum province. Clover, (Medicago sativa), mountain hispanic sainfoin (Hedysarum elegans), crossbred clover (Medicago varia), bird vetch (Vicia cracca), mountain vetch (Vicia alpestris), hairy vetch (Vicia villosa), mountain clover (Trifolium montanum), the three-headed clover (Trifolium trichocephalum), caucasian clover (Trifolium ambiguum), the crown of the eastern horn of grass (Coronilla orientatis), tawny grass crown (Coronilla varia) and yellow flowers gazelle (Lotus corniculatus) were investigated in present study.

Significant differences were observed among the legume forages in terms of dry matter (DM), crude ash (CA), ether extract (EE), crude protein (CP), organic matter (OM), ADF, NDF, ADL and RFV $(\mathrm{P}<0.01)$. The DMD, DMC and RFV of legume forages were determined as $60.92-73.26 \%, 2.46-3.90$ $\%$ and $116.69-221.18$ respectively.

The results from the present study showed that forages which were rich in EE, CP, CA and poor in NDF, ADF and ADL had satisfactory results in terms of DMC, DMD and RFV properties.
Keywords:

Legume forage

Chemical composition

Relative feed value

\section{Giriş}

Hayvanlardan elde edilen ürünlerin verim ve ürün kaliteleri ile hayvanların yeterli ve dengeli beslenmesi arasında doğru bir orantı mevcuttur. Ne kadar doğru bir besleme yapılırsa hayvansal ürün ve kalitesinde o derece bir artı̧s sağlanabilecektir. Bu durum; elde edilen ürünün fiyatlandırılmasını, pazarlanmasını, değerlendirilmesini, işlenmesini, muhafazasını kısacası üretimden tüketime kadar olan her aşamayı 
etkilemektedir. Dolayısıyla hayvanların yeterli ve dengeli beslenmesi ile elde edilen ürünler, bir yandan insanların sağlıklı beslenmesine önemli katkılar sağlarken, diğer yandan istihdam ve üretim imkânları oluşturarak bölge ve yurt ekonomisine önemli derecede katma değer sağlamaktadır.

Kaliteli kaba yemlerin tespit edilebilmesi için farklı kalite indeksleri içerisinde yer alan nispi yem değeri (NYD), ADF ve NDF içeriklerine ve hayvanların bu yemleri tüketme potansiyeli ile sağlayacağı enerji değerinin tahminine dayanır. Nispi yem değeri, yemlerin kalitelerinin belirlenebilmesinde ve pazarlanabilmesinde oldukça büyük bir önem arz etmektedir. Ancak, bunların yanında bazı dezavantajları da bulunmaktadır. Bunlar; kaba yemlerin sindirilebilir kuru madde (SKM) ve kuru madde tüketimlerinin (KMT) aynı kabul edilmesi, NYD'nin hesaplanmasında sadece ADF (asit çözücüde çözünmeyen yapısal karbonhidratlar) ve NDF (nötral çözücüde çözünmeyen yapısal karbonhidratlar) değerlerinin kullanılması, sindirilebilirliğin tespitinde asit çözücülerde çözünmeyen lignin (ADL) ve ham protein (HP) değerlerinin dikkate alınmaması olarak sıralanmaktadır (Rohweder ve ark., 1978; Moore, 1994).

Nispi yem değeri indeksi, tam çiçekteki yonca kuru otu (YKO)'nun ADF (\%41) ve NDF (\%53) içeriğinden hesaplanan 100 indeksini esas almaktadır. Bu değerin altına inildikçe yem kalitesi düşmekte, yükseldikçe artmaktadır. $\mathrm{Bu}$ sinıflandırma kapsamında, NYD indeksi değeri 150'nin üzerinde ise en iyi kalite, 125150 arasında ise 1. kalite, 103-124 arasında ise 2. kalite, 87-102 arasında ise 3. kalite, $75-86$ arasında ise 4 . kalite ve 75 'in altında ise 5. kalite olarak kabul edilmektedir (Rohweder ve ark., 1978; Ball ve ark., 1996; Richardson, 2001; Moore ve Undersander, 2002; Redfearn ve ark., 2006; Kaya, 2008; Canbolat ve Karaman, 2009).

Ülkemiz çayır ve meralarında doğal olarak oldukça fazla sayıda yem bitkisi çeşidi bulunmaktadır. Ancak, yanlış ve bilinçsiz uygulamalar nedeni ile bu alanlar, tahrip olmuş ve hayvan varlığımızın yem ihtiyacını karşılayamaz duruma gelmiştir. Bu araştırma, Erzurum ili merkez ve ilçe meralarında yetişen farklı baklagil yem bitkilerinin NYD'nin ortaya konulması amaciyla yapılmıştır.

\section{Materyal ve Yöntem}

\subsection{Yem Materyali}

Çalışmanın yem materyali olarak kullanılan baklagil yem bitki örnekleri 2012 yılı Haziran-Temmuz aylarında Erzurum ili ilçelerindeki meralardan toplanmıştır. Tortum ilçesindeki meradan $(1449 \mathrm{~m})$ yonca (Medicago sativa), dă̆ İspanyol korungası (Hedysarum elegans) ve tüylü fĭg (Vicia villosa), Pasinler ilçesindeki meralardan $(2010 \mathrm{~m}, 2247 \mathrm{~m}$ ve 2020 m) dağ üçgülü (Trifolium montanum), kuş fiğgi (Vicia cracca), alaca taç otu (Coronilla varia $L$.) ve melez yonca (Medicago varia), Şenkaya ilçesindeki meradan $(2543 \mathrm{~m})$ sarı çiçekli gazal boynuzu (Lotus corniculatus), Çat ilçesindeki meralardan $(2105 \mathrm{~m}$ ve $1919 \mathrm{~m}$ ) doğu taç otu (Coronilla orientatis), dağ fiği (Vicia alpestris) ve üç başlı üçü̈l (Trifolium trichocephalum), Oltu ilçesindeki meradan $(2431 \mathrm{~m})$ kafkas üçgülü (Trifolium ambiguum) baklagil yem bitkileri çiçeklenme döneminde hasat edilmiştir. Söz konusu 12 adet farklı baklagil yem bitkisi bu alanlardaki bitki kompozisyonunu temsil edebilmesi için 10 değişik yerden alınmış ve harmanlanmıştır (Canbolat ve Karaman, 2009).

\subsection{Kimyasal analizler}

Çalışma kapsamında ele alınan yemlerin kuru madde (KM) içerikleri $105{ }^{\circ} \mathrm{C}^{\prime}$ de 4 saat süre ile etüvde kurutularak, ham kül (HK) içerikleri kül firınında 550 ${ }^{\circ} \mathrm{C}^{\prime}$ de 4 saat yakılarak tespit edilmiştir. Azot (N) içeriğinin saptanmasında Kjeldahl metodundan yararlanılmıştır. Ham protein içeriği ise Nx6.25 formülü ile hesaplanmıştır (AOAC 1990). Ham yağ analizi, AOAC (1990)' da bildirilen yönteme göre yapılmıştır. Yemlerin hücre duvarı bileşenlerini oluşturan NDF, ADF ve ADL analizleri ise Van Soest ve ark. (1991) tarafindan bildirilen yönteme göre ANKOM 200 Fiber Analyzer (ANKOM Technology Corp. Fairport, NY, USA) cihazı kullanılarak yapılmıştır.

\subsection{Nispi yem değerinin belirlenmesi}

Yemlerin NYD'lerinin belirlenmesinde aşağıdaki eşitlikler kullanılmıştır (Van Dyke ve Anderson, 2000). \% KMS değerinin belirlenmesinde ADF değerlerinden yararlanılmıştır (Kaya, 2008).

$\% \mathrm{KMS}=88.9-(0.779 \times \% \mathrm{ADF})$

$\%$ KMT, NDF oranından yararlanılarak tespit edilmiştir.

$\% \mathrm{KMT}=120 / \mathrm{NDF}$

$\%$ KMT ve \% KMS oranları belirlendikten sonra NYD'leri aşağıdaki formül ile hesaplanmıştır.

$\mathrm{NYD}=\%$ KMS x \% KMT x 0.775

\subsection{Istatistik analizler}

Araştırmada elde edilen veriler varyans analizine (SPSS 12.0 paket programında) (General linear model) (Statisca, 1933) tabi tutulmuştur. Gruplara ait ortalamalar Duncan testi ile karşılaş̧ırılmıştır (Duncan, 1955). Çalışmada incelenen yemlerin KMT, KMS ve NYD ile yemlerin kimyasal kompozisyonu arasındaki ilişki basit korelasyon analizleri ile belirlenmiştir (Snedecor ve Cochran, 1976).

\section{Bulgular}

Çalışmada ele alınan baklagil yem bitkilerine ait besin madde içerikleri Çizelge 1'de, KMS, KMT ve NYD ile ilgili veriler Çizelge 2'de, KMS, KMT ve 
NYD ile besin maddeleri içerikleri arasındaki korelasyonlar ise Çizelge 3 'te verilmiştir.

\section{Tartışma ve Sonuç}

\subsection{Yemlerin kimyasal bileşimi}

Kimyasal kompozisyon bakımından yemler arasında farkl11ıklar önemli bulunmuştur $(\mathrm{P}<0.01)$ (Çizelge 1). Araştırma materyali yem bitkisi örneklerine ait HK içerikleri \%3.65 ile \%8.96 arasında değişmiştir. En yüksek ve en düşük HK içerikleri kuş fiğinde (\%8.96) ve dağ fiğinde (\%3.65) tespit edilmiştir.

Baklagil yem bitkilerine ait HK içerikleri bu konuda yapılan çalışmalarda bildirilen sonuçlarla karşılaştırıldığında, elde edilen sonuçların bazı araştırıcıların (Karabulut ve ark., 2007) bulguları ile benzer, bazı araştırıcıların (Şahin ve ark., 2011) bulgularından daha yüksek ve bazı araştııcıların (Khazal ve ark., 1994; Valentin ve ark., 1999; Abaş ve ark., 2005; Bayraktar, 2005; Kamalak, 2005; Karabulut ve ark., 2006; Özkan, 2006; Polat ve ark., 2007; Şahin ve ark., 2011) bulgularından ise daha düşük olduğu tespit edilmiştir.

Rumende mikrobiyal faaliyetlerin normal olarak gerçekleşebilmesi, yani arzu edilen miktarda mikrobiyal protein sentezi için, ruminant rasyonlarının kuru madde esasına göre \%13 HP içermesi $(9 \mathrm{mg} \mathrm{NH} / 100 \mathrm{ml}$ rumen sıvısı) gerektiği bildirilmiştir (Aksoy ve ark., 2000; Norton, 2012). İncelenen baklagil yem bitkilerinin HP içerikleri \%14.95-20.61 arasında değişmiş̧ir. En yüksek ve en düşük HP oranı içerikleri sirasıyla alaca taç otunda $(\% 20.61)$ ve dağ üçgülü (\%14.95) yem bitkisinde tespit edilmiştir.

Araştırma materyali yem bitkilerinin HP içerikleri diğer çalışmalarla karşılaştıııldığında bazı araştırıcıların (Serin ve ark., 1998; Abaş ve ark., 2005; Bayraktar, 2005; Şahin ve ark., 2011) bulgularından yüksek, kimi araştıııcıların (Albayrak ve Ekiz, 2005; Özkan, 2006; Karabulut ve ark., 2007; Canbolat ve Karaman, 2009) bulguları ile benzer ve kimi araştırıcıların (Khazal ve ark., 1994; Bakoğlu ve ark., 1999; Valentin ve ark., 1999; Kamalak, 2005; Yavuz, 2005; Karabulut ve ark., 2006; Polat ve ark., 2007) bulgularından ise daha düşük olduğu gözlenmiştir.

Baklagillerde lignin / selüloz oranının 1.09 olduğu buğdaygillerde lifli kısmın oranının baklagillerden daha yüksek olduğu ve ruminantların baklagil lifini \%40-50 civarında sindirdikleri bildirilmiştir (Smith ve ark., 1972; Buxton, 1990;Van Soest ve ark., 1991; Buxton ve Mertens, 1995; Buxton ve Redfearn, 1996; Cherney ve ark., 1997; Rayburn, 1997; Edward ve Rayburn, 1998; Robinson, 2003).

Baklagil yem bitkisi örneklerine ait hücre NDF, ADF ve ADL oranları sirasiyla \%31.16-48.90, \%20.0735.91 ve \%6.00-12.35 arasında belirlenmiștir. En yüksek ve en düşük NDF içerikleri sırasıyla, melez yonca $(\% 48.90)$ ve alaca taç otunda $(\% 31.16)$, en yüksek ve en düşük ADF içerikleri sarı çiçekli gazal boynuzu (\%35.91) ve alaca taç otunda (\%20.07), en yüksek ve en düşük $\mathrm{ADL}$ içerikleri doğu taç otunda (\%12.35) ve alaca taç otunda (\%6.00) tespit edilmiştir.

Çizelge 1. Baklagil yem bitkilerinin kimyasal kompozisyonu, \% (KM’de)

\begin{tabular}{|c|c|c|c|c|c|c|c|c|}
\hline \multicolumn{9}{|c|}{ Kimyasal Kompozisyon } \\
\hline Yem bitkileri & KM & HK & $\mathrm{OM}$ & $\mathrm{HP}$ & $\mathrm{HY}$ & NDF & $\mathrm{ADF}$ & $\mathrm{ADL}$ \\
\hline Dağ İspanyol korungası & $92.10^{\text {cd }}$ & $4.34^{\mathrm{c}}$ & $95.66^{\mathrm{a}}$ & $15.08^{\mathrm{e}}$ & $2.56^{\mathrm{a}}$ & $48.26^{\mathrm{ab}}$ & $32.07^{\mathrm{cd}}$ & $10.45^{\mathrm{bc}}$ \\
\hline Tüylü fiğ & $92.86^{\mathrm{bc}}$ & $4.35^{\mathrm{c}}$ & $95.65^{\mathrm{a}}$ & $18.38^{\mathrm{bc}}$ & $1.42^{\mathrm{b}}$ & $47.62^{\mathrm{ab}}$ & $31.17^{\text {cde }}$ & $7.64^{\text {efg }}$ \\
\hline Yonca & $93.76^{\mathrm{abc}}$ & $7.47^{\mathrm{ab}}$ & $92.53^{\mathrm{ab}}$ & $17.89^{\mathrm{cd}}$ & $1.38^{\mathrm{bcd}}$ & $43.28^{\mathrm{bc}}$ & $29.61^{\mathrm{def}}$ & $7.88^{\text {defg }}$ \\
\hline Dağ üçgülü & $92.70^{\mathrm{c}}$ & $3.85^{\mathrm{c}}$ & $96.15^{\mathrm{a}}$ & $14.95^{\mathrm{e}}$ & $1.40^{\mathrm{bc}}$ & $41.04^{\mathrm{cd}}$ & $31.40^{\mathrm{cd}}$ & $11.34^{\mathrm{ab}}$ \\
\hline Sarı çiçekli gazal boynuzu & $93.63^{\mathrm{abc}}$ & $4.86^{\mathrm{c}}$ & $95.14^{\mathrm{a}}$ & $15.51^{\mathrm{e}}$ & $1.06^{\mathrm{e}}$ & $46.03^{\mathrm{ab}}$ & $35.91^{\mathrm{a}}$ & $9.66^{\mathrm{bcd}}$ \\
\hline Doğu taç otu & $93.50^{\mathrm{abc}}$ & $8.55^{\mathrm{a}}$ & $91.45^{\mathrm{c}}$ & $18.34^{\mathrm{bc}}$ & $1.25^{\mathrm{cd}}$ & $37.32^{\mathrm{d}}$ & $28.39^{\mathrm{ef}}$ & $12.35^{\mathrm{a}}$ \\
\hline Dağ fiği & $94.46^{\mathrm{ab}}$ & $3.65^{\mathrm{c}}$ & $96.35^{\mathrm{a}}$ & $19.70^{\mathrm{ab}}$ & $1.06^{\mathrm{e}}$ & $44.66^{\mathrm{abc}}$ & $33.51^{\mathrm{abc}}$ & $6.66^{\mathrm{ef}}$ \\
\hline Kuş fiği & $93.60^{\mathrm{abc}}$ & $8.96^{\mathrm{a}}$ & $91.04^{\mathrm{c}}$ & $16.42^{\mathrm{de}}$ & $1.02^{\mathrm{e}}$ & $45.64^{\mathrm{abc}}$ & $32.63^{\mathrm{bcd}}$ & $8.21^{\mathrm{def}}$ \\
\hline Kafkas üçgülü & $93.46^{\mathrm{abc}}$ & $6.84^{\mathrm{b}}$ & $93.16^{\mathrm{b}}$ & $16.76^{\text {cde }}$ & $1.26^{\mathrm{cd}}$ & $40.94^{\text {cd }}$ & $28.11^{\mathrm{f}}$ & $7.88^{\mathrm{defg}}$ \\
\hline Alaca taç otu & $90.76^{\mathrm{d}}$ & $3.99^{\mathrm{c}}$ & $96.01^{\mathrm{a}}$ & $20.61^{\mathrm{a}}$ & $1.32^{\mathrm{bcd}}$ & $31.16^{\mathrm{e}}$ & $20.07^{\mathrm{g}}$ & $6.00^{g}$ \\
\hline Üç başlı üçgül & $93.66^{\mathrm{abc}}$ & $8.66^{\mathrm{a}}$ & $91.34^{\mathrm{c}}$ & $17.38^{\mathrm{cd}}$ & $1.24^{\mathrm{d}}$ & $45.43^{\mathrm{abc}}$ & $32.13^{\text {cd }}$ & $8.22^{\text {def }}$ \\
\hline Melez yonca & $95.16^{\mathrm{a}}$ & $4.71^{\mathrm{c}}$ & $95.29^{\mathrm{a}}$ & $16.15^{\mathrm{de}}$ & $1.26^{\mathrm{cd}}$ & $48.90^{\mathrm{a}}$ & $35.37^{\mathrm{ab}}$ & $9.08^{\text {cde }}$ \\
\hline SEM & 0.381 & 0.390 & 0.390 & 0.427 & 0.035 & 1.150 & 0.713 & 0.466 \\
\hline Önemlilik düzeyi & $* *$ & $* *$ & $* *$ & $* *$ & $* *$ & $* *$ & $* *$ & $* *$ \\
\hline
\end{tabular}

a-g: Aynı sütunda farklı harfler ile gösterilen ortalamalar arasındaki farklılıklar önemlidir. ${ }^{* *}=\mathrm{P}<0.01$, SEM: Ortalamanın standart hatas1 
Çizelge 2. Baklagil yem bitkilerine ait kuru madde sindirilebilirlikleri, kuru madde tüketimi ve nispi yem değerleri

\begin{tabular}{lccc}
\hline Yem bitkileri & KMS (\%) & KMT $(\%)$ & NYD \\
\hline Dağ İspanyol korungası & $63.92^{\mathrm{de}}$ & $2.50^{\mathrm{d}}$ & $123.71^{\mathrm{ef}}$ \\
Tüylü fĭg & $64.61^{\mathrm{cde}}$ & $2.53^{\mathrm{d}}$ & $126.84^{\mathrm{def}}$ \\
Yonca & $65.83^{\mathrm{bcd}}$ & $2.77^{\mathrm{cd}}$ & $141.53^{\text {cde }}$ \\
Dağ üçgülü & $64.43^{\mathrm{de}}$ & $2.93^{\mathrm{bc}}$ & $146.27^{\mathrm{bcd}}$ \\
Sarı ççekli gazal boynuzu & $60.92^{\mathrm{g}}$ & $2.61^{\mathrm{cd}}$ & $123.18^{\mathrm{ef}}$ \\
Doğu taç otu & $66.78^{\mathrm{bc}}$ & $3.22^{\mathrm{b}}$ & $166.57^{\mathrm{b}}$ \\
Dağ fiği & $62.79^{\mathrm{efg}}$ & $2.69^{\mathrm{cd}}$ & $130.78^{\mathrm{def}}$ \\
Kuş fiği & $63.47^{\mathrm{def}}$ & $2.63^{\mathrm{cd}}$ & $129.62^{\mathrm{def}}$ \\
Kafkas üçgülü & $67.00^{\mathrm{b}}$ & $2.94^{\mathrm{bc}}$ & $152.44^{\mathrm{bc}}$ \\
Alaca taç otu & $73.26^{\mathrm{a}}$ & $3.90^{\mathrm{a}}$ & $221.18^{\mathrm{a}}$ \\
Üç başlı üçgül & $63.87^{\mathrm{de}}$ & $2.64^{\mathrm{cd}}$ & $130.80^{\mathrm{def}}$ \\
Melez yonca & $61.35^{\mathrm{fg}}$ & $2.46^{\mathrm{d}}$ & $116.69^{\mathrm{f}}$ \\
\hline SEM & 0.555 & 0.089 & 5.150 \\
\hline Önemlilik Düzeyi & $* *$ & $* *$ & $* *$
\end{tabular}

a-g: Aynı sütunda farklı harfler ile gösterilen ortalamalar arasındaki farklılıklar önemlidir. SEM= Ortalamanın standart hatası, $\mathrm{KMS}=$ Kuru madde sindirilebilirliği, $\mathrm{KMT}=$ Kuru madde tüketimi, $\mathrm{NYD}=$ Nispi yem değeri, $* *=\mathrm{P}<0.01$

Söz konusu yem bitkilerinin ADF, NDF ve ADL içerikleri, bazı araştırıcıların (Khazal ve ark., 1994; Valentin ve ark., 1999; Kamalak, 2005; Özkan, 2006; Karabulut ve ark., 2007; Seresinhe ve ark., 2012) bulguları ile benzer, kimi araștırıcıların (Yavuz, 2005; Şahin ve ark., 2011) bulgularından ise daha düşük bulunmuştur. Tüylü fiğ ve gazal boynuzu yem bitkileri hücre duvarlarının incelendiği diğer çalışmalardaki NDF ve ADF içeriklerinin, bu çalışmadaki elde edilen verilerden düşük, $\mathrm{ADL}$ içeriklerinin ise daha yüksek olduğu görülmüştür (Karabulut ve ark., 2006; Canbolat ve Karaman, 2009).

Çalışmadaki yem bitkilerinin kimyasal içerikleri ile NYD'lerinin, diğer çalışmalarda bildirilen içeriklerle farklı olmasının nedenleri arasında yemin kaynağı dışında, iklim, toprak, bitki tür ve çeşidi, yemin hasat zamanı ve yemin vejetasyon dönem farklılıkları gibi faktörler sayılabilir.

4.2. Yem bitkilerinin kuru madde sindirilebilirlikleri, kuru madde tüketimleri ve nispi yem değerleri ile kimyasal bileşimleri arasındaki korelasyonlar

Baklagil yem bitkilerinin \%KMS, \%KMT ve NYD'leri Çizelge 2'de, kimyasal bileşimler ile \%KMS, $\%$ KMT ve NYD arasındaki korelasyonlar ise Çizelge 3 'te verilmiştir.

Çalışmada ele alınan yem bitkilerinin \%KMS, $\%$ KMT ve NYD içerikleri sirasıyla \%60.92-73.26, \%2.46-3.90 ve 116.69-221.18 arasında değişmiştir. En yüksek KMS, KMT ve NYD içerikleri alaca taç otunda (\%73.26, \%3.90 ve 221.18), en düşük KMS sarı çiçekli gazal boynuzunda (\%60.36), en düşük KMT ve NYD ise melez yoncada (\%2.46 ve 116.69$)$ belirlenmiştir.

Çalışmadaki baklagil yem bitkilerine ait \%KMS, \%KMT ve NYD'leri bazı çalışmalarda (Adesogan ve ark., 2006; Canbolat ve ark., 2006; Canbolat ve Karaman, 2009) bildirilen bulgular ile benzer, Yavuz (2005) tarafindan bildirilen değerlerden ise yüksek bulunmuştur.

Araştırmada incelenen baklagil yem bitkilerine ait \%KMS, \%KMT ve NYD ile HP içerikleri arasında pozitif $(\mathrm{P}<0.01)$, KM değerleri arasında ise negatif $(\mathrm{P}<0.01)$ bir ilişki tespit edilmiştir. Bu bulgu, Canbolat ve Karaman (2009) ile Karabulut ve ark. (2007)'nın bulguları ile desteklenmektedir.

Çizelge 3. Baklagil yem bitkilerine ait kimyasal kompozisyon ile KMS, KMT ve NYD arasındaki korelasyonlar

\begin{tabular}{lcccc}
\hline \multicolumn{5}{c}{ Besin Maddeleri Bileşimi } \\
\hline & KM & HK & HP & HY \\
\hline KMS & $-0.644^{* *}$ & -0.005 & $0.575^{* *}$ & 0.053 \\
KMT & $-0.626^{* *}$ & -0.069 & $0.575^{* *}$ & -0.158 \\
NYD & $-0.652^{* *}$ & -0.073 & $0.593^{* *}$ & -0.103 \\
\hline
\end{tabular}

KMS: Kuru madde sindirilebilirliği; KMT: Kuru madde tüketimi, NYD: Nispi yem değerleri; **: $\mathrm{P}<0.01$

Sonuç olarak, çalışmada incelenen baklagil yem bitkilerinin besin maddeleri içeriklerinin NDF, ADF ve ADL değerleri bakımından önemli düzeyde farklılıklar gösterdiği tespit edilmiştir. Araştırmada en yüksek KMS, KMT ve NYD indeksi değerleri alaca taç otu yem 
bitkisinde olduğu görülmüş, ayrıca çalışmada ele alınan tüm yem bitkilerinin NYD'leri bakımından yüksek kalite sınıfında yer aldıkları belirlenmiştir. Çalışmamızda elde edilen bu bilgilerin Erzurum ili ve daha genel anlamda Doğu Anadolu Bölgesi kapsamında yapılacak mera ıslah çalışmalarında göz önüne alınması durumunda daha kaliteli meraların tesisi mümkün olabilecektir. $\mathrm{Bu}$ sayede, bir yandan bölgedeki yetiştiriciler hayvanlarını daha kaliteli meralarda yetiştirme ve dolayısıyla daha yüksek gelir elde etme imkânına sahip olacak, diğer yandan ise artan hayvansal üretim düzeyine bağlı olarak ülke ekonomisine katkı sağlanmış olacaktır.

\section{Teşekkür}

$\mathrm{Bu}$ çalışma, Prof. Dr. Muhlis MACİT danışmanlı̆̆ında, 2011/334 proje numarasıyla Atatürk Üniversitesi BAP komisyonu tarafindan desteklenen ve Esra GÜRSOY tarafindan hazırlanan doktora tezinden özetlenmiştir.

\section{Kaynaklar}

Abaş, İ., Özpınar, H., Kutay, H.C., Kahraman, R., Eseceli, H., 2005. Determination of the metabolizable energy (ME) and net energy lactation (NEL) contents of some feeds in the marmara region by in vitro gastTecnique. Turk $\mathrm{J}$. Vet. Anim. Sci., 29: 751-757.

Adesogan, A.T., Sollenberger, L.E., Moore, J.E., 2006. Forage quality. In: Florida Forages Handbook. (Ed. C.G. Chambliss and M. B. Adjei) Univ. of Florida. Cooperative Extension Services.

Aksoy, A., Macit, M., Karaoğlu, M., 2000. Hayvan Besleme Ders Kitabı. Atatürk Üniv. Ziraat Fak. Zootekni Böl. Erzurum, 179-199.

Albayrak, S., Ekiz, H., 2005. An investigation on the estabilishment of artifical pasture under Ankara's ecological conditions. Turk J. Agric For., 29: 6974.

AOAC, 1990. Official method of anallysis. Association of Official Analytical Chemists. 15th. Edition, 6688, Washington, DC., USA.

Bakoğlu, A., Koç, A., Gökkuş, A., 1999. Erzurum yöresi çayır ve meralarındaki yaygın bitki türlerinin ömür uzunluğu, çiçeklenmeye başlama tarihi ve ot kalitesi ile ilgili bazı özellikleri. Tr. J. Of Agriculture and Foresty, 23(4): 951-957.

Ball, D.M., Hoveland, C.S., Lacefield, G.D., 1996. Forage quality. In: Southern Forages (2nd edition). Potash \& Phosphate Institute and Foundation for Agronomic Research. Norcross, GA., 124-132.

Bayraktar, E., 2005. Tekirdağ koşullarında bazı yem bitkilerinin farklı gelişme dönemlerinde kök ve gövdelerinde bitkilerin kimi besin maddelerinin değişimi. Yüksek Lisans Tezi. Tarla Bitkileri Ana Bilim Dalı, Tekirdağ, 86s.

Buxton, D., 1990. Cell-Wall components in divergent germplasm of four perennial forage grass species. Crop Sci., 30: 402-408.

Buxton, D.R., Mertens, D.R., 1995. Ouality-Related characteristics of forages in forages volume II. The Science of Grassland Agriculture, Lowa State Univ. Pros., Ames, Lowa, USA, 83-96.

Buxton, D.R., Redfearn, D.D., 1996. Plant limitations to fiber digestion and utilization. 37th. Annual Ruminant Nut. Conf., 14 April, Washington, 814818.

Canbolat, Ö., Kamalak, A., Özkan, C.Ö., Erol, A., Şahin, M., Karakaş, E., Özkose, E., 2006. Prediction of relative feed value of alfalfa hays harvested at different maturity stages using in vitro gas production. Livestock Research for Rural Development, 18(2): 27.

Canbolat, Ö., Karaman, Ş., 2009. Bazı baklagil kaba yemlerinin in vitro gaz üretimi, organik madde sindirilebilirliği, nispi yem değeri ve metabolik enerji içeriklerinin karşılaştırılması. Tarım Bilimleri Dergisi, 15(2): 188-195, Ankara.

Cherney, D.J.R., Cherney, J.H., Davidson, A.H., 1997. Characterization of legume and grass residues following in vitro and in sacco ruminal digestion. Proc. The XVIII. International Grassland Cong., June 8-17, Winnipeg and Saksatoon, Session, 17: 17-23.

Duncan, D.B., 1955. Mutiple range and multiple F tests. Biometrics, 11: 1-42.

Edward, B., Rayburn, D., 1998. Using forage test to identify improvements in forage management west virginia university extension service, PO Box 6108, Morgantown.

Kamalak, A., 2005. Bazı kaba yemlerin gaz üretim parametreleri ve metabolik enerji içerikleri bakımdan karşılaştırılması. KSÜ. Fen ve Mühendislik Dergisi, 8(2): 116-120.

Karabulut, A., Canbolat, Ö., Kamalak, A., 2006. Effect of maturity stage on the nutritive value Value of birdsfoot trefoil (Lotus corniculatus L.) hays. Lotus Newsletter, 36(1): 11-21.

Karabulut, A., Canbolat, Ö., Kalkan, H., Gürbüzol, F., Sucu, E., Filya, İ., 2007. Comparison of in vitro gas production, metabolizable energy, organic matter digestibility and microbial protein production of some legume hays. Asian-Agust. J. Anim. Sci., 20(4): 517-522.

Kaya, Ş., 2008. Kaba yemlerin değerlendirilmesinde göreceli yem değeri ve göreceli kaba yem kalite indeksi. Türk Bilimsel Derlemeler Dergisi, 1(1): 59-64.

Khazal, K., Boza, J., Orskov, E.R., 1994. Assessment of phenolics-related antinutritive effects in mediterranean browse: a comparison between the use of the gas production technique with or without insoluble polyvinylpolpyrrolidone or nylon bag. Anim. Feed. Sci. Technol., 49: 133149.

Moore, J.E.,1994. Forage quality indices: Development 
and Application. In: Forage Quality, Evaluation and Utilization. (ed. Fahey, Jr. G.C.). ASA, CSSA, SSSA, Madison, WI, 977-998.

Moore, J.E., Undersander, D.J., 2002. Relative forage quality: Alternative to relative feed value and quality index. Proceedings 13th Annual Florida Ruminant Nutrition Symposium, 16-32.

Norton, B.W., 2012. The Nutritive value of tree legumes.

http://www.fao.org/ag/AGP/AGPC/doc/Pubicat/G utt-shel/x5556e0j.htm. pp. 1-10 (Erişim Tarihi: 7 Kasim 2012).

Özkan, Ç.Ö. ,2006. Farklı dönemlerde hasat edilen bazı baklagil yem bitkilerinden sindirim derecesinden ve metabolik enerji değerlerinin in vitro gaz ekniği ile belirlenmesi. Yüksek Lisans Tezi. K.S.İ.Ü. Fen. Bil. Ens., Kahramanmaraş, 39s.

Polat, M., Şayan, Y., Özkul, H., Önenç, S.S., 2007. Kaba yemlerin çeşitli inkübasyon periyotlarındaki in vitro metabolik enerji değerleri. Ege Üniv. Ziraat Fak. Derg., 44(1): 113-122.

Rayburn, E.B., $1997 . \quad$ Available at www.caf.wvu.edu/ forage (Erişim tarihi: 6 Kasım 2012).

Redfearn, D., Zhang, H., Caddel, J., 2006. Forage quality interpretations. Oklahoma Cooperative, Extension Service F-2117, http://pods.dasnr.okstate.edu/docushare/dsweb/Get /Document-2557/F-2117web.pdf (Erişim Tarihi: 6 Kasim 2012).

Richardson, C., 2001. Relative feeding value (RFV), an indicator of hay quality. OSO Extension Fact F2117, http://clay.agr.okstate.edu/alfalfa/webnews /quality3.

Robinson, P.H., 2003. Estimating alfalfa hay and corn silage energy levels, uc davis equations using NDF and ADF. Available at http://animalscience.ucdavis.edu/faculty/robinson/ Articles/Fulltext/Pdf/Web200309.pdf (Erişim Tarihi: 6 Kasım 2012).

Rohweder, D.A., Barnes, R.F., Jorgensen, N., 1978. Proposed hay grading standards based on laboratory analyses for evaluating quality. Journal of Animal Science, 47: 747-759.
Seresinhe, T., Madushika, S.A.C., Seresinhe, Y., Lal, P.K., Ørskov, K., 2012. Effects of tropical high tannin non legume and low tannin legume browse mixtures on fermentation parameters and methanogenesis using gas production technique. Asian-Aust. J. Anim. Sci., 25(10): 1404-1410.

Serin, Y., Gökkuş, A., Tan, M., Koç, A., Çomaklı, B., 1998. Sun'i çayır tesisinde kullanılabilecek uygun yem bitkileri ve karışımlarının belirlenmesi. Tr. J. Of Agriculture and Foresty, 22: 13-20.

Snedecor, G.W., Cochran, W.,1976. Statistical methods. The Iowa State Univ. Pres. Amer. IA., USA.

Smith, L.W., Goering, H.K., Gordon, C.H., 1972. Relationships of forage compositions with rates of cell digestion and digestibility of cell walls. J. Dairy Sci., 55: 1140-1147.

Statistica, 1993. Statistica for Windows (Release 4.3), Sat Soft, Inc. Tulsa. OK.

Şahin, M., Üçkardeş, F., Canbolat, Ö., Kamalak, A., Atalay, A.İ., 2011. Ruminant beslemede kullanılan bazı yemlerin kısmi gaz üretim zamanlarının tahmini. Kafkas Univ. Vet. Fak. Derg., 17(5): 731734.

Valentin, S.F., Williams, P.E.V., Forbes, J.M., Sauvant, D., 1999. Comparison of the in vitro gas production technique and the nylon bag degradability technique to measure short and long term processes of degradation of maize silage in dairy cows. Animal Feed Science Technology, 78: 81-99.

Van Dyke, N.J., Anderson, P.M., 2000. Interpreting a forage analysis. Alabama cooperative extension. Circular ANR-890.

Van Soest, P.J., Robertson, J.D., Lewis, B.A., 1991. Methods for dietary fibre, neutral detergent fibre and non-starch polysaccharides in relation to animal nutrition. Journal of Dairy Science, 74: 3583-3597.

Yavuz, M., 2005. Bazı ruminant yemlerinin nispi yem değeri ve in vitro sindirim değerlerinin belirlenmesi. GOÜ. Ziraat Fakültesi Dergisi, 22(1): 97-101. 